\title{
REVERSE SHOULDER PROSTHESIS: REVIEW DARI FITUR IMAGING DAN KOMPLIKASINYA
}

\author{
Sharanya Ramachandran \\ Program Studi Pendidikan Dokter, Fakultas Kedokteran Universitas Udayana
}

(sharu63@yahoo.com)

\section{ABSTRAK}

Latar belakang: reverse shoulder prosthesis adalah prosthesis yang telah digunakan secara klinis di Eropa sejak 1985 dan telah disetujui untuk digunakan di Amerika Serikat pada tahun 2004. Prosthesis unik ini memiliki dasar melekat pada glenoid, yang memegang komponen yang berbentuk bola, sedangkan komponen humerus yang meliputi polietilen yang terdapat di dalamnya adalah datar. Desain ini adalah konfigurasi "terbalik" yang terlihat dengan artroplasti konvensional, di mana komponen yang berbentuk bola merupakan bagian dari komponen humerus. Indikasiuntukprosthesis terbalikadalah: (1) arthritis yang sangat nyeridikaitkandenganrobekan rotator-cuff yang tidakdapat diperbaiki(robekanrotatorcuffarthropathy), (2) hemiarthroplasty gagaldengan robekanrotator-cuff yang tidakdapat diperbaiki, (3) pseudoparalysisyang masif, robekan rotator-cuff yang tidak dapatdiperbaiki, (4) beberaparekonstruksisetelahreseksitumor, dan(5) beberapapatah tulangbahutidak dapatdiperbaikiataureconstructabledengantekniklain. Prosthesisini dapatmenghasilkanpengurangan yang signifikan dalamrasa sakitdanbeberapaperbaikandalamfungsiuntuksebagian besarindikasiyang disebutkan. Namun,konfigurasiunikdantantanganpenyisipandapatmengakibatkantingginya insidenberbagaikomplikasiyang tidak biasa. Beberapakomplikasi, seperti dislokasikomponen, miripdenganpenggantianbahukonvensional. Komplikasilain, sepertibentukanskapuladanpatah stress acromialyang unikuntukprostesisini. Kesimpulan: Konfigurasidariprosthesisterbalik, penampilanradiografi yang normaldankomplikasipotensialterkaitpenggunaan.

Kata Kunci: reverse shoulder prosthesis

\section{PENDAHULUAN}

Conventional total shoulder arthroplasty (TSA) mengganti shoulder ball dan kantong sendi dengan komponen humerus tersusun dari metal dan komponen glenoid tersusun dari polietilen. TSA hanya bisa diimplan bila ada manset rotator yang berfungsi dan tulang glenoid yang adekuat sebagai tempat komponen glenoid harus ditempelkan. Untuk pasien-pasien tanpa manset rotator yang berfungsi, penggunaan hemiarthroplasty yang hanya mengandung komponen kepala humerus merupakan terapi yang direkomendasikan. Sayangnya, penggunaan komponen humerus saja pada pasienpasien arthritis dan manset rotator non fungsional tidak mengurangi nyeri dan memperbaiki rentang gerak pada banyak pasien. 


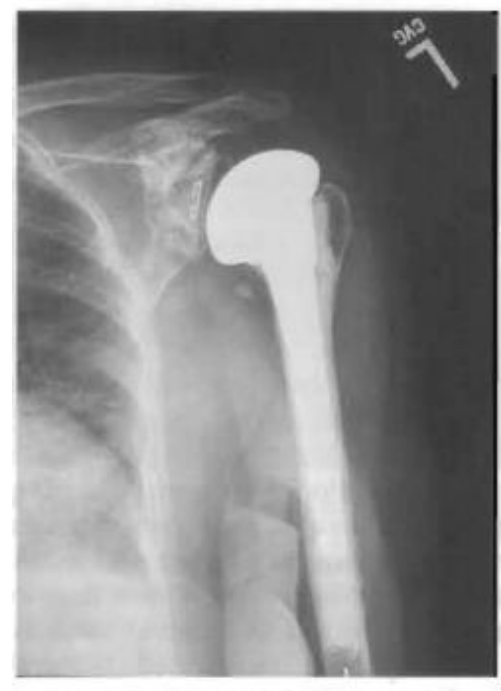

Gambar 1. Wanita 70 tahun yang menjalani arthroplasty bahu kiri total karena atrhrosis degenerative. Radiograph anteroposterior bahu kiri menunjukkan arthroplasty total standard

Pada tahun 1985, seorang ahli bedah Prancis bernama Grammont mendesain sebuah prosthesis unik yang ditujukan untuk pasien-pasien yang memiliki arthritis bahu dan rotator-cuffyang tak berfungsi. Desain baru yang radikal ini membalikkan hubungan tradisional antara ball dengan kantongnya dan mengimplantasi ball ke dalam alas yang direkatkan pada glenoid dengan sekrup, sedangkan komponen humerus proksimal memiliki sisipan polietilen yang menyerupai kantong. Prostesis ini telah dimodifikasi beberapa kali dan diimplan oleh ahli-ahli bedah di Eropa selama 20 tahun. Tujuan dari desain yang unik ini tidak hanya untuk mengurangi nyeri, tetapi juga untuk memperbaiki pergerakan bahu untuk pasien-pasien dengan rotator-cuffyang tak berfungsi.

Pada bulan Maret 2004, alat yang unik ini diluncurkan oleh FDA untuk digunakan oleh ahli-ahli bedah di Amerika Serikat. Dalam waktu singkat, ahli bedah ortopedi telah ahli menggunakan alat ini dan antusiasme terhadap alat ini pun meningkat. Tujuan dari artikel ini adalah untuk mengulas mengenai indikasi prosthesis bahu dan memperkenalkan tiga sistem yang saat ini tersedia di pasaran, menjelaskan mengenai tampilan imaging dari prosthesis normal, dan untuk mengilustrasikan dan mendiskusikan komplikasi-komplikasi yang mungkin timbul dari alat ini.

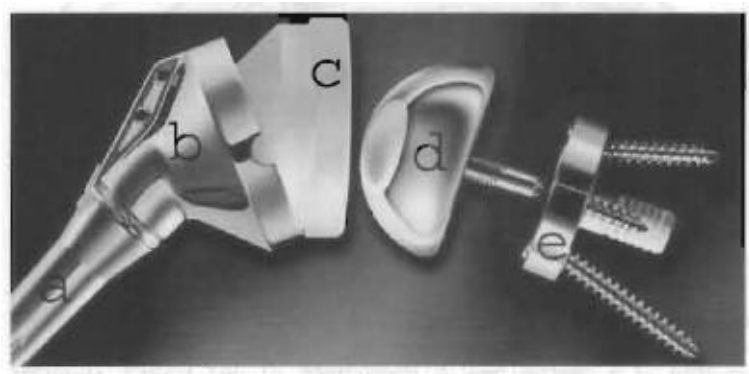

Gambar 2A-E. Komponen humeral dan glenoid dari reverse shoulder prosthesis A. Shaft B. epiphysis C. Polyethylene D. Glenosphere E. Dasar

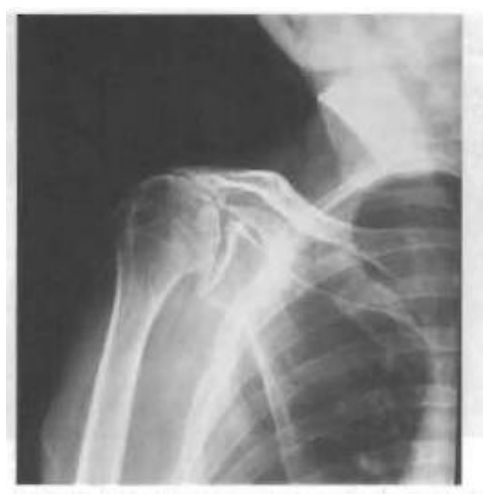

Gambar 3. Laki-laki 68 tahun dengan decreasing strength dan range of motion pada bahu kanan, pemeriksaan fisik menunjukkan elevasi aktif terbatas sampai $30^{\circ}$. Radiograph anteroposterior pada bahu kanan menunjukkan subluksasi anteroposterior kepala humerus dengan arthropathy rotator-cuff

\section{INDIKASI PADA REVERSE SHOULDER PROSTHESIS}

Indikasi utama dari reverse prostesis adalah adanya nyeri dan artropaty dari robekan rotator-cuff. Dimana kondisi tersebut memiliki karakteristik adanya superior subluksasi dari head-humerus pada gabungannya dengan artrosis glenohumeral. Dalam 
pemeriksaan, pasien biasanya akan menunjukkan berkurangnya range of motion dan kelemahan pada saat abduksi dan rotasi eksternal. Seringkali, pasien juga sebelumnya telah mengalami kegagalan pada saat perbaikan cedera dari rotator-cuff, yang dapat menyebabkan nyeri dan subluksasi superior.

Indikasi tersering kedua untuk prostesis adalah kegagalan pada proses artroplasty bahu dimana rotator-cuff tidak berfungsi, yang menyebabkan subluksasi superior dari prostesis tradisional. Seperti juga pada kondisi yang terjadi pada pasien dengan insersi hemiartroplasty untuk rotator-cuff tear arthropathy, atau insersi hemiartroplasty untuk fraktur kominutif tiga atau empat bagian dari humerus proksimal.

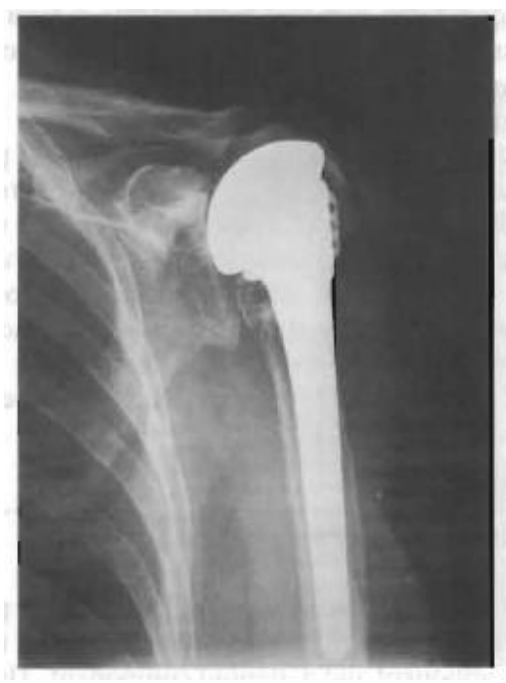

Gambar 4. Wanita79 tahun yang menjalani hemiarthroplasty bahu kiri untuk fracture proksimal humerus 6 tahun yang lalu. Radiograph anteroposterior pada bahu kiri menunjukkan kegagalan heniathroplasty dengan subluksasi superior pada humerus karena rotator-cuff tear

Indikasi lain untuk reverse prostesis adalah pasien dengan rheumatoid arthritis yang terdapat hubungan dengan artropathy rotator-cuff. Penggunaan dari prostesis juga telah dapat dijelaskan untuk pasien dengan post-traumatic arthritis dengan malunion atau nonunion dari tuberositas tulang dengan disfungsi rotator-cuff, untuk fraktur kominutif akut tiga atau empat bagian fraktur dari humerus proksimal, dan untuk rekonstruksi bahu setelah adanya beberapa tumor.

\section{Komponen Prostesis}

Pada saat ini, terdapat 3 jenis reverse prosthesis yang tersedia dipasaran. Alat dasar meliputi komponen humeral dan glenoid. Komponen glenoid pada 3 sistem merupakan yang paling mirip dan terdiri atas pasak sentral dan skrup yang terletak didalam lubang bor dibagian tengah glenoid (Gambar 5A). Pada saat dasar ini telah terpasang, 4 buah skrup diletakkan melewati dasar kedalam glenoid dan skapula dengan tujuan untuk mengunci piringan kedalam tulang. Setelah dasar"ini terkunci, sebuah "gleno-sphere" ditanam menggunakan skrup sentral kedalam dasar (Gambar 5B). Komponen Glenoid tidak dieratkan karena didesain untuk tumbuh dalam tulang. Akan tetapi, apabila tulang tersebut lunak, semen digunakan untuk meningkatkan fixasi antara dari dasar dan skrup. Sepertiga sistem yang ada dipasaran memiliki skrup sentral daripada pasak sentral untuk mengunci piringan ke glenoid.

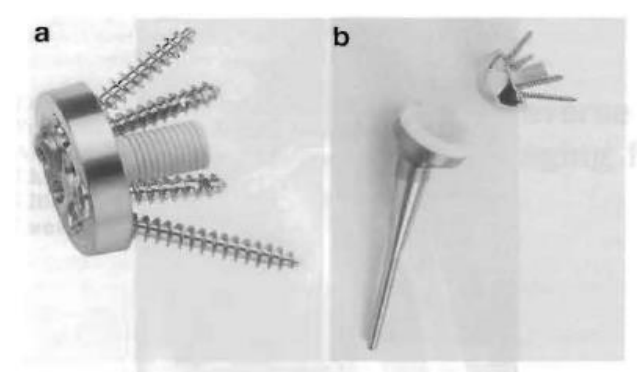

Gambar 5. A.Dasardan surgical screws dari sistem reverse prosthesis.Breverse shoulder sistem yang menunjukkan komponen humeral dengan sisipan plastik berpasangan dengan komponen glenoid, dimana sekarang hemisphere sudah diikatkan 
Komponen humeral terdiri dari sebuah batang dan bagian proximal yang disatukan bersama-sama oleh sebuah galur sekrup (Gambar 5B). Komponen polyethylene cekung kemudian dimasukkan menuju ujung proximal pada batang humeral, dan komponen polyethylene ini memiliki kurvatura radius yang hampir serupa dengan gleno-sphere (Gambar 5B). pada salah satu sistem, komponen polyethylene merupakan komponen yang lebih besar dibandingkan 2 sistem lainnya (Gambar 6B). Batang humeral ini biasanya direkatkan, meskipun tersedia pula batang humeral yang tidak direkatkan di Eropa. Komponen humeral dan gleno-sphere berartikulasi satu sama lain dan terletak pada orientasi yang tepat dari komponen dan pada tegangan jaringan lunak untuk tetap pada posisinya (Gambar 7). Batang humeral panjang untuk revisi kasus tersedia dan biasanya direkatkan ke dalam piringan.

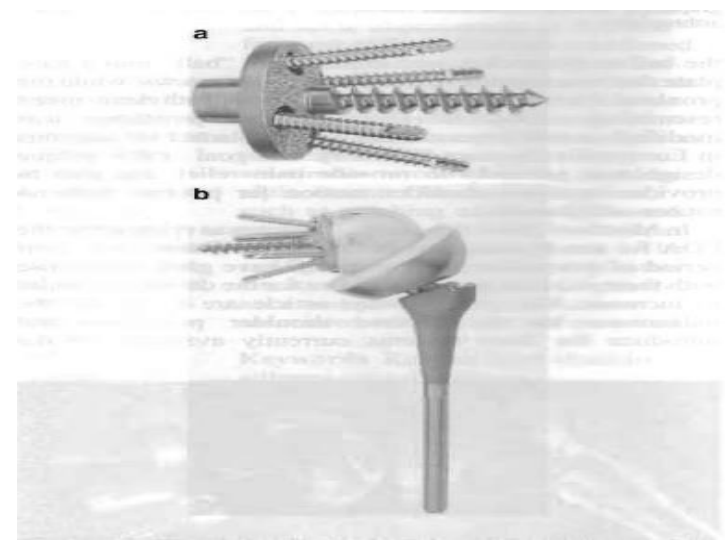

Gambar 6. Adasar dan surgical screws pada sistem reverse prosthesis dimana dasarmemiliki sekrup sentral daripada pasak sentral. B. Komponen humeral memiliki polyethylene yang lebih besar dan komponen humeral berbeda dengan yang beredar dipasaran.

Secara biomekanik, reverse prosthesis bekerja dengan merubah arah dan menarik otot deltoid. Pada pasien yang tidak memiliki "rotator-cuff", bagian kepala humeral cenderung untuk mengalami subluksasi dibagian superior ketika otot deltoid berkontraksi (Gambar 8). Vector ini tidak dapat dikoreksi dengan menggunakan hemiarthroplasty standard pada pasien yang tidak memiliki "rotatorcuff". Reverse prosthesis dapat mengkoreksi keabnormalan vector ini
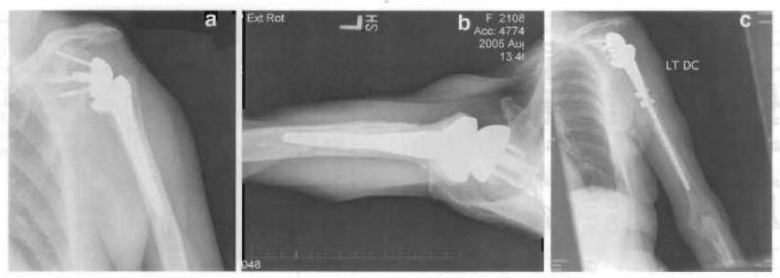

Gambar 7.A. Radiograph anteroposterior dari bahu kiri wanita 76 tahun yang menjalani implantasi "reverse prosthesis" pada arthropathy rotator-cuff. B. Gambaran axilla pasien yang sama. C. Radiograph anteroposterior pada bahu kiri wanita 75 tahun yang menjalani revisi arthroplasty bahu total yang gagal.dengan menggunakan "long stem reverse prosthesis"

Dengan memindahkan pusat rotasi dari lengan secara lateral dan mengalihkan arah tarikan otot deltoid (Gambar 8B). Pemindahan pusat rotasi dengan menggunakan prosthesis memudahkan deltoid untuk mengelevasi lengan meskipun sendi bahu memiliki sedikit atau bahkan tidak sekalipin memiliki "rotator-cuff tendons"

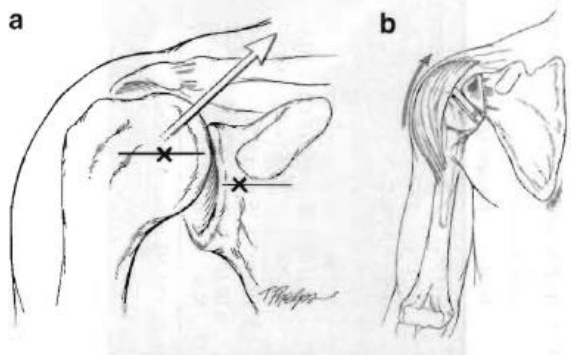

Gambar 8. A. Pada bahu pasien tanpa tendon rotator-cuff, terdapat sedikit pengekangan relative ke subluksasi antero-superior dari kepala humeral menuju glenoid ketika pasien berusaha untuk mengangkat lengannya. Tarikan pada otot deltoid 
memperparah kondisi ini dengan menarik kearah superior dan medial (tanda panah) B. Pada reverse prosthesis, pengangkat otot deltoid kembali seperti semula, memudahkan untuk menarik humerus naik dan keluar (tanda panah)

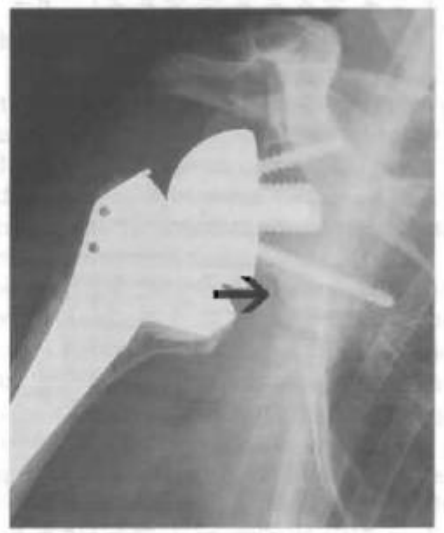

Gambar 9. Radiograph anteroposterior bahu kanan laki laki 86 tahun yang menjalani shoulder replacement karena arthropathy rotator-cuff. Tanda panah menunjukkan scapular notching, tetapi tidak ada dampak pada notching ini dan tidak terdapat tanda penipisan

\section{Clinical Outcome}

Pada umumnya, "reverse prosthesis" menyediakan pemecahan masalah yang nyata pada bahu yang rusak dengan arthritis berat dan "irreparable rotator-cuff' $\quad(8,9,12,13,15-19)$. Terdapat perkembangan yang meningkat pada mayoritas pasien dalam hal perbaikan nyeri dan "range of motion"

Akan tetapi "reverse prosthetic", secara tekhnik masih merupakan suatu tantangan bagi para ahli bedah karena komplikasinya yang umum (Tabel 2). Werner et al melaporkan komplikasi mayor dan minor pada $50 \%$ studi kohort 58 pasien; dengan ratio operasi kembali mencapai 33\% (19). Frankle melaporkan komplikasi $17 \%$ dari 60 pasien dan $12 \%$ gagal dan membutuhkan revisi kembali. Frankle berpendapat bahwa periode krisis pemasangan prosthesis ini terjadi pada 2 tahun pertama setelah implantasi.

\begin{tabular}{|c|c|c|c|c|c|c|c|c|c|c|}
\hline \multirow[t]{2}{*}{ Author } & \multirow[t]{2}{*}{$n$} & \multirow[t]{2}{*}{ Age (ninge) } & \multirow[t]{2}{*}{ Dingnosis' } & \multicolumn{2}{|c|}{ Indication, $n(\%)$} & \multirow[t]{2}{*}{ Length FU (range) } & \multicolumn{2}{|l|}{ Resulth, $n$ (\%) } & \multicolumn{2}{|c|}{ Average constant score (range) } \\
\hline & & & & Primary & Revision" & & Satisfied & Dissatisfied & Preop & Postop \\
\hline Vaienti 2001 [18] & 39 & $70(55-87)$ & 1.4 & $36(92 \%)$ & $3(8 \%)$ & 84 months $(60-108)$ & NS & NS & 21 & 63 \\
\hline Rittmeister 2001 [20] & 7 & $60(38-63)$ & 6 & $7\left(100 \mathrm{P}_{\mathrm{n}}\right)$ & 0 & 54.3 months $(48-73)$ & $7(100 \%)$ & $\mathrm{N} / \mathrm{S}$ & 17 & 63 \\
\hline Jucobs $2001[14]$ & 14 & $72(54-80)$ & $1,4,6$ & $9(64 \%)$ & $5(36 \%)$ & months (16-37) & NS & NiS & 179 & 56.7 \\
\hline Boulhhia $2002[9]$ & 16 & $77(66-80)$ & 1,2 & $16(100 \%)$ & 0 & 35 months $(24-65)$ & $16(100 \%)$ & Nis & $22(5-34)$ & $59(41-78)$ \\
\hline De Wilde 2003 [10] & 13 & $49(26-68)$ & 5 & $13(100 \%)$ & 0 & 36 months $(5-120)$ & N/S & N/S & $39(5-100)$ & $72.5(30 .-90)$ \\
\hline Sirveaux 2004 (16) & 80 & $73(60-86)$ & i & $80(100 \%)$ & 0 & 44.5 months $(24-97)$ & Nis & NS & $22.6(4-50)$ & $655(34-85)$ \\
\hline Wener 2005 [19] & 58 & $68(44-84)$ & 1.4 & $17(290 \%)$ & $41(71 \%)$ & imum 24) & NS & N/S & $29(3-53)$ & $64(10-100)$ \\
\hline Bollean 2005 [8] & 45 & $\mathrm{NA}$ & 1, 3,4 & $26(58 \%)$ & $19(42 \%)$ & 40 months $(24-72)$ & $35(78 \%)$ & $10(22 \%)$ & $17(14-20)$ & $59(53-65)$ \\
\hline Frankle 2005 [12] & 60 & $71(34-86)$ & $1,2,6$ & $60(100 \%)$ & 0 & 33 & $57(95 \%)$ & $3(5 \%)$ & $34.3^{c}(0-65)$ & $68.2^{2}(15-100)$ \\
\hline De Wilde 2005 [i]] & 4 & $42(23-51)$ & 5 & $4(10000)$ & 0 & 38 months $(24-60)$ & NS & NiS & NS & $84.5(70-91)$ \\
\hline
\end{tabular}

Tabel 1. Kesimpulan laporan outcomes klinik dengan reverse shoulder prosthesis

\begin{tabular}{|c|c|c|c|c|c|c|}
\hline \multirow[t]{2}{*}{ Auttor } & \multicolumn{5}{|c|}{ Complication, $n(\%)$} & \multirow[t]{2}{*}{ Failure or revision, $n$ (\%) } \\
\hline & Total & Loosening" & Dislocation & Infection & Others & \\
\hline Valenti $2001[18]$ & $6(15 \%)$ & $4 \mathrm{GL}(10 \%)$ (3 unscrew) & 0 & $2(5 \%)$ & None & $3(8 \%)$ \\
\hline Ritmeister $2001[20]$ & $4(50 \%)$ & $3 \mathrm{GL}(38 \%)$ & 0 & $\mathrm{I}(13 \%)$ & 3 acromial fractures (transactromial approach) & $1(13 \%)$ \\
\hline Jacobs $2001[14]$ & Nis & NS & NS & NS & NS & NS \\
\hline Boulahia $2002[9]$ & $4(25 \%)$ & 1 GL. $(6 \%)$ & $1(1 \%)$ & 0 & 1 phlebitis, I hematoma & $2(13 \%)$ \\
\hline De Wilde 2003 [10] & $5(39 \%)$ & NS & $4(31 \%)$ & $2(15 \%)$ & None & $1(8 \%)$ \\
\hline Sirveaux 2004 [16] & $11(14 \%)$ & $8(10 \%)(7 \mathrm{GL}, 1 \mathrm{HL})$ & Nis & $1(1 \%)$ & None & $3(4 \%)$ \\
\hline Wemer 2005 [19] & $29(50 \%)$ & $4(7 \%)(3 \mathrm{GL}, 1 \mathrm{HL})$ & $5(9 \%)$ & $6(10 \%)$ & 12 bematomas, I nerve lesion, 4 fracturs, 1 inlay dislocution & $6(10 \%)$ \\
\hline Boilean $2005[8]$ & $10(13 \%)$ & $5 \mathrm{HL}(11 \%)$ & $3(7 \%)$ & $2(4 \%)$ & 1 periprosthetic fracture, I glenoid fracture & $10(22 \%)$ \\
\hline Frankle $2005[12]$ & $10(17 \%)$ & $6 \mathrm{GL}(12 \%)$ & $1(2 \%)$ & $3(5 \%)$ & 1 scapular fracture, 3 acromial fractures & $7(12 \%)$ \\
\hline De Wilde 2005 [II] ] & NS & 0 & $\mathrm{~N} / \mathrm{s}$ & 0 & None & 0 \\
\hline
\end{tabular}

Tabel 2. Kesimpulan laporan komplikasi dengan reverse shoulder prosthesis

\section{KOMPLIKASI}

Beberapa komplikasi yang dapat terjadi dengan penggunaan reverse prosthesis sama dengan komplikasi yang ditimbulkan dengan arthroplasty shoulder yang dilakukan pada pasien dengan rekonstruksi kompleks dari bahu, antara lain hematoma, infeksi dan kerusakan saraf. Infeksi dapat menyebabkan kelonggaran komponen dan akhirnya kegagalan.

Komplikasi yang sering terjadi setelah implantasi reverse prosthesis adalah penyatuan scapula inferior dengan komponen humeral (Gambar.9). Penyatuan ini diyakini karena kontak antara bagian proksimal humerus dan scapula 
inferior. Penyatuan ini telah diklasifikasikan oleh Nero (Gambar.10) dan muncul segera setelah implantasi, biasanya menjadi stabil setelah 1 tahun pada sebagian besar pasien. Masih ada kontroversi apakah penyatuan ini menimbulkan gejala klinis.
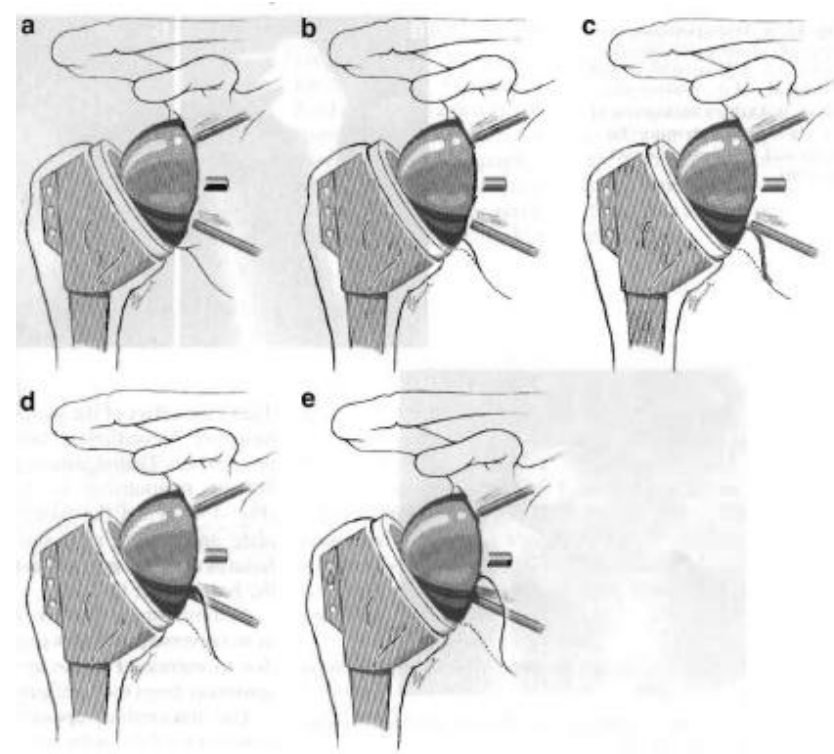

Gambar 10. Klasifikasi Nero tentang progresivitas penyatuan skapula. A) Grade 0 : tidak ada penyatuan, B) Grade 1 : penyatuan kecil, C) Grade 2 : penyatuan dengan kondensasi (stabil), D) Grade 3 : evolutive notch (erosi dari skrup inferior), E) Grade 4 : kelonggaran glenoid awal.

Komplikasi lain yang dapat terjadi adalah dislokasi dari prosthesis (Gambar.11).Radiografi tegak lurus satu sama lain diperlukan untuk membuat diagnosis tersebut (Gambar.12). Ketidakstabilan prosthesis mungkin disebabkan oleh ketegangan jaringan lunak yang tidak adekuat, malposisi dari komponen atau kelonggaran dari komponen dengan gerakan.

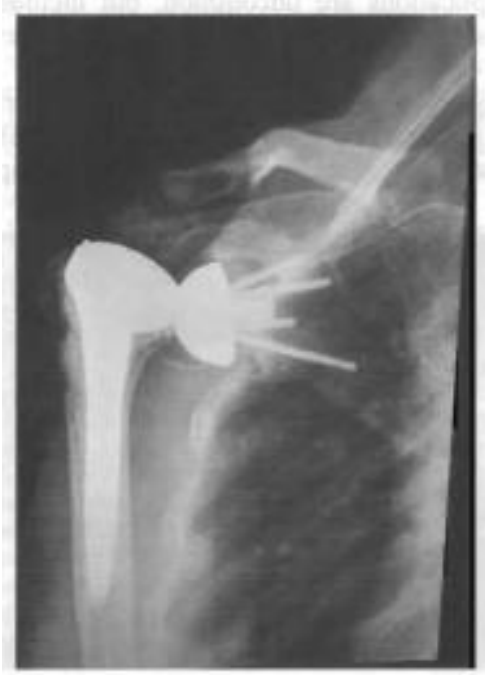

Gambar 11. Wanita 82 tahun dilakukan reverse shoulder arthroplasty 7 bulan sebelumnya. Dia mengalami onset nyeri ketika menggerakakan bahunya dengan posisi abduksi dan rotasi eksternal. Radiografi oblik dari bahu kanannya menunjukkan dislokasi dari reverse prosthesis.
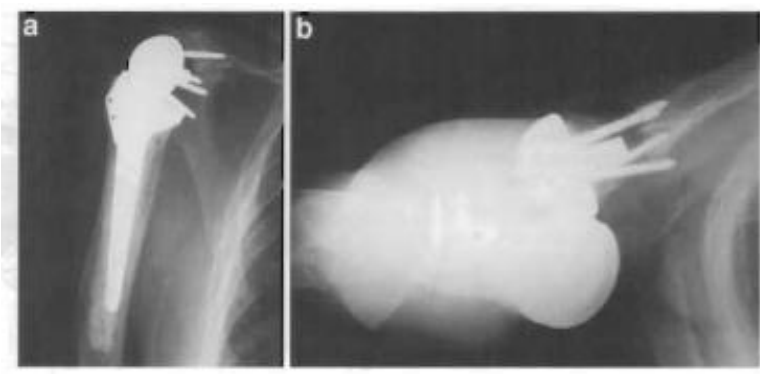

Gambar 12.A) Radiografi anteroposterior pada bahu kanan menunjukkan dislokasi reverse prosthesis pada pasien yang berbeda. B) Radiografi aksilari pada pasien yang sama menunjukkan dislokasi prosthesis.

Garis radiolusen sekitar dasar pada glenoid telah diobsevasi, namun sebagian orang meyakini gambaran ini disebabkan oleh penutupan dari bidang gleno pada perlekatannya terhadap dasar. Pergeseranpada dasar bisa dilihat, tapi hubungannya dengan garis radiolusen belum diketahui (Gambar.13). Ketika fiksasi dari dasargagal, mangkok 
dan bola glenoid dapat bergeser dan bergerak. Walaupun kegagalan skrup dapat terlihat, itu mengindikasikan kegagalan yang pasti terjadi pada dasar(Gambar.14).

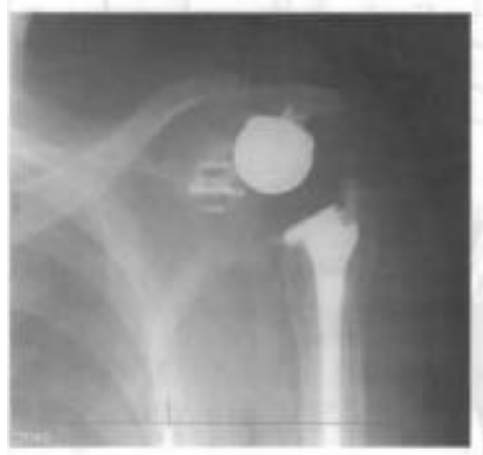

Gambar 13. Radiografi anteroposterior dari bahu kiri menunjukkan pergeseran dari dasar glenoid.

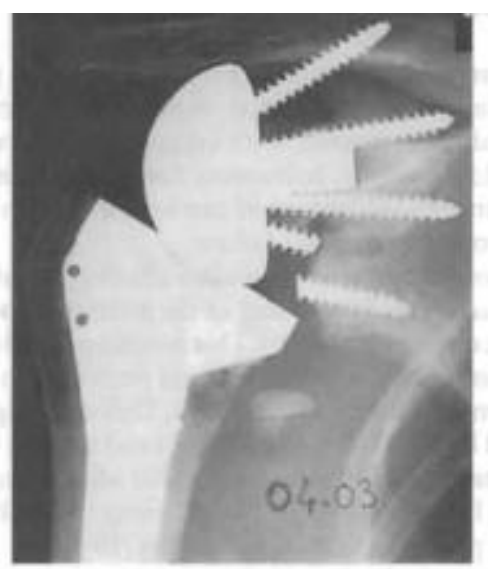

Gambar 14. Radiografi anteroposterior dari bahu kanan menunjukkan fraktur skrup pada dasar glenoid, yang pada kasus ini berhubungan dengan migrasi superior dari dasar glenoid.

Acromial stress fractures telah dilaporkan pada penggunaan reserve prosthesis (Gambar.15). Ini diyakini karena peningkatan tekanan yang dialami bagian posterior akromion dari konfigurasi prosthesis.

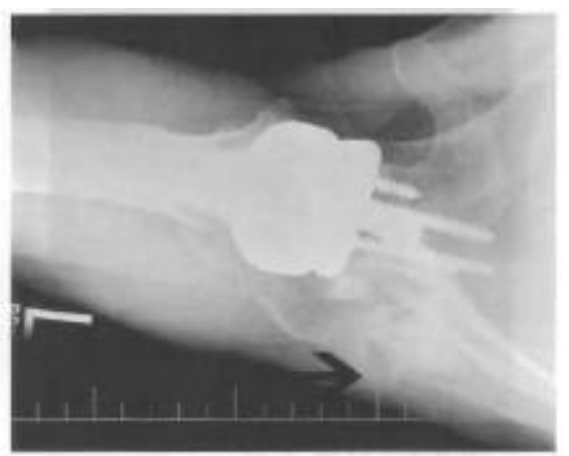

Gambar 15. Laki-laki 65 tahun, dilakukan reverse shoulder prosthesis placement dengan rotator-cuff arthroplasty. Empat bulan setelah operasi, ia mengalami nyeri yang signifikan pada bahunya, yang lebih dominan di again posterior. Dia menyangkal riwayat trauma. Radiografi aksilari dari bahu kanan menunjukkan acromial stress fracture.

Bagian batang komponen humeral terlihat lebih seperti sebuah standard total shoulder stemkecuali itu cenderung melebar secara proksimal di dekat ujung atas humerus. Komplikasi bagian humeral adalah tidak biasa, namun menyertakan radiolusen, kemiringan dari komponen humeral jika tidak menyatu, dan patah (Gambar.16).

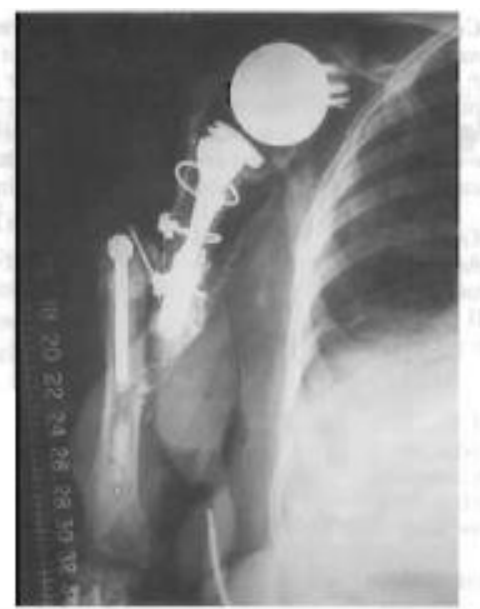

Gambar 16. Wanita 79 tahun, dengan rotator-cuff arthroplasty yang dilakukan arthroplasty bahu total. Dia mengalami nyeri yang signifikan setelah penonjolan lenganny. Radiografi anteroposterior dari bahu kanan menunjukkan patah pada batang humerus. 
Gambaran radiologi memainkan peranan vital untuk mendeteksi dan menentukan karakteristik komplikasi operasi yang potensial terjadi. Radiografi masih diandalkan untuk diagnosis awal dari komplikasi tersebut. Radiografi harus meliputi gambaran anterior-posterior dan gambaran aksila. Gambaran anterior-posterior pada rotasi internal dan eksternal memungkinkan visualisasi dasar dari sudut pandang yang berbeda. Meskipun, teknik CT yang maju dengan pemetaan 3D mungkin berguna untuk meningkatkan deteksi terhadap abnormalitas tersebut. Denganvolume3D-CT yang diberikan, alat penanda yang dihubungkandenganperangkat

kerasbedahsecaranyatadikurangi, secara potensial menimbulkanpeningkatan

demonstrasipatologitulanghalusdibandingkandengan radiograf, meskipun perludicatatbahwareformasimultiplanardapatmemb erikandetaillebihdari penggambaran3Ddengan teknik penggambaran permukaandanlebih dipilihuntukdiagnosisaktualdaninterpretasi.

\section{Kesimpulan}

Reverse shoulder

prosthesisadalahprotesthesisinovatifyang

dirancanguntukpasiendengan rotator-cuff arthropathy tingkat lanjut, gagalhemiarthroplastydengan kelainanrotatorcuffatausubluksasisuperiordarihumeruskarena kelainan rotator-cuff. Komponenprotesadantampilan pencitraannormaltelahditinjau,

karenamemilikimanifestasiradiografidarikomplikasiu mum yangterkaitdenganitu. Kelangsunganjangkapanjangimplan initidak diketahui, danpraktisiharus menyadaripotensiuntuk membongkardankegagalandarikomponendari waktu ke waktu

\section{DAFTAR PUSTAKA}

1. Byrd RB, Miller WE, Carr DT, Payne WS, Woolner LB. The roentgenographic appearance of squamous cell carcinoma of the bronchus. Mayo Clinic Proceedings 1968;43:327-332.MedlineWeb of Science

2. Forster BB, Muller NL, Miller RR, Nelems B, Evans KG. Neuroendocrine carcinomas of the lung: clinical, radiologic, and pathologic correlation. Radiology 1989;170:441-445.MedlineWeb of Science

3. Pearlberg JL, Sandler MA, Lewis JW Jr, Beute GH, Alpern MB. Small-cell bronchogenic carcinoma: CT evaluation. Am J Roentgenol 1988;150:265268.MedlineWeb of Science

4. Dahnert W. Chest Disorders. In: Dahnert W, ed. Radiology Review Manual. 3rd edition. Baltimore, Williams and Wilkins, 1996; pp. 346-346.

5. Fraser RG, Parre JAP. Diagnosis of diseases of the chest. 4th edition. Philadelphia, W.B. Saunders, 1999; pp. 1142-1143.

6. Shin MS, Jackson LK, Shelton RW Jr, Greene RE. Giant cell carcinoma of the lung. Clinical and roentgenographic manifestations. Chest 1986;89:366-369.CrossRefMedlineWeb of Science

7. Hyer JD, Silvestri G. Diagnosis and staging of lung cancer. Clin Chest Med 2000;21:95106.CrossRefMedlineWeb of Science

8. Webb WR. Radiologic evaluation of the solitary pulmonary nodule. Am J Roentgenol 1990;154:701708.MedlineWeb of Science

9. Remy-Jardin M, Remy J, Giraud F, Marquette $\mathrm{CH}$. Pulmonary nodules: detection with thick-section 
ISSN: 2089-9084

ISM, VOL. 4 NO.1, SEPTEMBER-DESEMBER, HAL 74-82

spiral CT versus conventional CT. Radiology 1993;187:513-520.MedlineWeb of Science

10. Brink JA, Heiken JP, Semenkovich J, Teefey SA, McClennan BL, Sagel SS. Abnormalities of the diaphragm and adjacent structures: findings on multiplanar spiral CT scans. Am J Roentgenol 1994;163:307-310.CrossRefMedlineWeb of Science

11. Kuriyama K, Tateishi R, Kumatani T, et al. Pleural invasion by peripheral bronchogenic carcinoma: assessment with three-dimensional helical CT. Radiology 1994;191:365-369.MedlineWeb of Science

12. Aquino SL, Vining DJ. Virtual bronchoscopy. Clin Chest Med 1999;20:725-730.CrossRefMedlineWeb of Science

13. Ohnesorge B, Flohr T, Schaller S, et al. The technical bases and uses of multi-slice CT. Radiologe 1999;39:923-931.CrossRefMedlineWeb of Science

14. McCollough $\mathrm{CH}$, Zink FE. Performance evaluation of a multi-slice CT system. Med Phys 1999;26:22232230.CrossRefMedlineWeb of Science

15. Patz EF Jr, Erasmus JJ, McAdams HP, et al. Lung cancer staging and management: comparison of contrast-enhanced and nonenhanced helical CT of the thorax. Radiology 1999;212:56-60.MedlineWeb of Science

16. Cascade PN, Gross BH, Kazerooni EA, et al. Variability in the detection of enlarged mediastinal lymph nodes in staging lung cancer: a comparison of contrast-enhanced and unenhanced CT. Am J Roentgenol 1998;170:927-931.MedlineWeb of Science
17. Gefter WB. Magnetic resonance imaging in the evaluation of lung cancer. Semin Roentgen 1990;25:73-84.CrossRef

18. Hatabu H, Stock KW, Sher S, et al. Magnetic resonance imaging of the thorax. Past, present, and future. Clin Chest Med 1999;20:775803.CrossRefMedlineWeb of Science

19. Batra P, Brown K, Steckel RJ, Collins JD, Ovenfors CO, Aberle D. MR imaging of the thorax: a comparison of axial, coronal, and sagittal imaging planes. J Comp Assist Tomogr 1988;12:75-81.MedlineWeb of Science

20. Aitken K, Armstrong P. Clinical imaging for staging lung cancer. Imaging 1992;4:15-22.

21. Webb WR, Jensen BG, Sollitto R, et al. Bronchogenic carcinoma: staging with MR compared with staging with CT and surgery. Radiology 1985;156:117124.MedlineWeb of Science

22. Padovani B, Mouroux J, Seksik L, et al. Chest wall invasion by bronchogenic carcinoma: evaluation with MR imaging. Radiology 1993;187:3338. MedlineWeb of Science

23. Erasmus JJ, Patz EF Jr. Positron emission tomography imaging in the thorax. Clin Chest Med 1999;20:715724.CrossRefMedlineWeb of Science

24. Duhaylongsod FG, Lowe VJ, Patz EF Jr, Vaughn AL, Coleman RE, Wolfe WG. Lung tumor growth correlates with glucose metabolism measured by fluoride-18 fluorodeoxyglucose positron emission tomography. Annals of Thoracic Surgery 1995;60:1348-1352.CrossRefMedlineWeb of Science 